\title{
A New Species of the Spider Genus Argyrodes (Araneae: Theridiidae) from Japan Previously Misidentified with $A$. fissifrons
}

\author{
Takafumi Chida ${ }^{1)}$ and Akio Tanikawa ${ }^{2)}$
}

\section{千田高史 ${ }^{1)}$ ・谷川明男 ${ }^{2)}$ ：これまで A. fissifrons に誤同定されていた 日本産イソウロウグモ属（クモ目：ヒメグモ科）の 1 新種}

\begin{abstract}
Bösenberg and Strand (1906) recorded Argyrodes fissifrons O. PickardCambridge, 1869 from Japan. Their identification is proved to be wrong by the examination on the type specimens. The spider is described as a new species under the name Argyrodes kumadai sp. nov. On the other hand, A. menlunensis Zhu et Song, 1991 is newly synonymized with $A$. fissifrons.
\end{abstract}

Bösenberg and Strand (1906) recorded Argyrodes fissifrons O. Pickard-Cambridge, 1869 from Japan. The spider is very common in Japan except northern part of Honshu Island and Hokkaido Island. The spider is often found in the web of Agelena limbata Thorell, 1879 and Cyrtophora moluccensis (Doleschall, 1857). Mr. Ken-ichi Kumada (personal communication) found that the features of the female epigynum and the internal genitalia of Japanese specimens which had been regarded as $A$. fissifrons did not agree with those described by Chrysanthus (1975) who collected specimens from Lennel Island. The objective of the present study is to clarify whether or not the Japanese spider regarded as $A$. fissifrons is really identical with $A$. fissifrons.

Chrysanthus (1963) reported $A$. fissifrons from New Guinea Island based on the male specimen. He confirmed his identification by comparing the specimen with one male specimen from the syntypes preserved in the Natural History Museum, London. He did not examine the female type specimen because no females were obtained from New Guinea Island. In 1975, he made several figures of female genital organ of $A$. fissifrons in order to compare them with those of Argyrodes wolf Strand, 1911, but he did not examine the female type specimen at that time. In addition, his male and female specimens were collected from different localities, so they could belong to different species.

The feature of the male palp of Japanese specimens regarded as A. fissifrons exactly agrees with the figure made by Chrysanthus (1963). However the structure of female

1) Laboratory of Bioresource Technology, Department of Agricultural and Environmental Biology, The University of Tokyo, 1-1-1, Yayoi, Bunkyo-ku, Tokyo, 113-8657 Japan

東京大学大学院農学生命科学研究科生物資源創成学研究室 干113-8657 東京都文京区弥生 1-1-1

2) Shichirigahama Senior High School, 2-3-1, Shichirigahama-higashi, Kamakura-shi, Kanagawa, 248-0025 Japan

神奈川県立七里ガ浜高等学校７248-0025 神奈川県鎌倉市七里ガ浜東 2-3-1

Accepted May 8, 1999 
genital organ does not agree with the figure made by Chrysanthus (1975). Therefore it was necessary to examine the female type specimen to solve this problem. We examined the male and the female type specimens of $A$. fissifrons preserved in the Natural History Museum, London. As a result, we have clarified that neither the Japanese spider nor the Lennel spider was a real $A$. fissifrons.

Though the male of Japanese spider cannot be distinguished from the male type specimen of $A$. fissifrons even by the structure of genital organ, female epigynum of Japanese spider is quite different from that of the female type specimen. We could not find any female specimen of $A$. fissifrons among many specimens collected from various parts of Japan. As the Japanese spider cannot be identified with any other species of the genus Argyrodes, it will be described as a new species in this paper. We have also identified the Lennel spider (Chrysanthus 1975, figs. 156-159) as A. wolfi.

Furthermore, we suggest that Argyrodes menlunensis Zhu et Song, 1991 is a junior synonym of $A$. fissifrons, because epigynum of $A$. menlunensis described by Zhu \& Song (1991) exactly agrees with that of the female type specimen of $A$. fissifrons.

All the type specimens designated in this paper are deposited in the collection of the Zoological Department of National Science Museum, Tokyo.

We wish to express our hearty thanks to Dr. Paul Hillyard and Ms. Janet Margerison-Knight, the Natural History Museum, London, for loaning invaluable specimens. We are greatly indebted to Dr. Tadashi Miyashita, University of Tokyo, for critical reading of the manuscript of this paper. Our sincere thanks are also due to Dr. Zhu Mingsheng, Hebei Teachers University, Mr. Ken-ichi Kumada, Mie, Mr. Akira Shinkai, Tokyo, and Mr. Tomoyuki Kimura, Kanagawa, for offering literatures and many specimens used in this study.
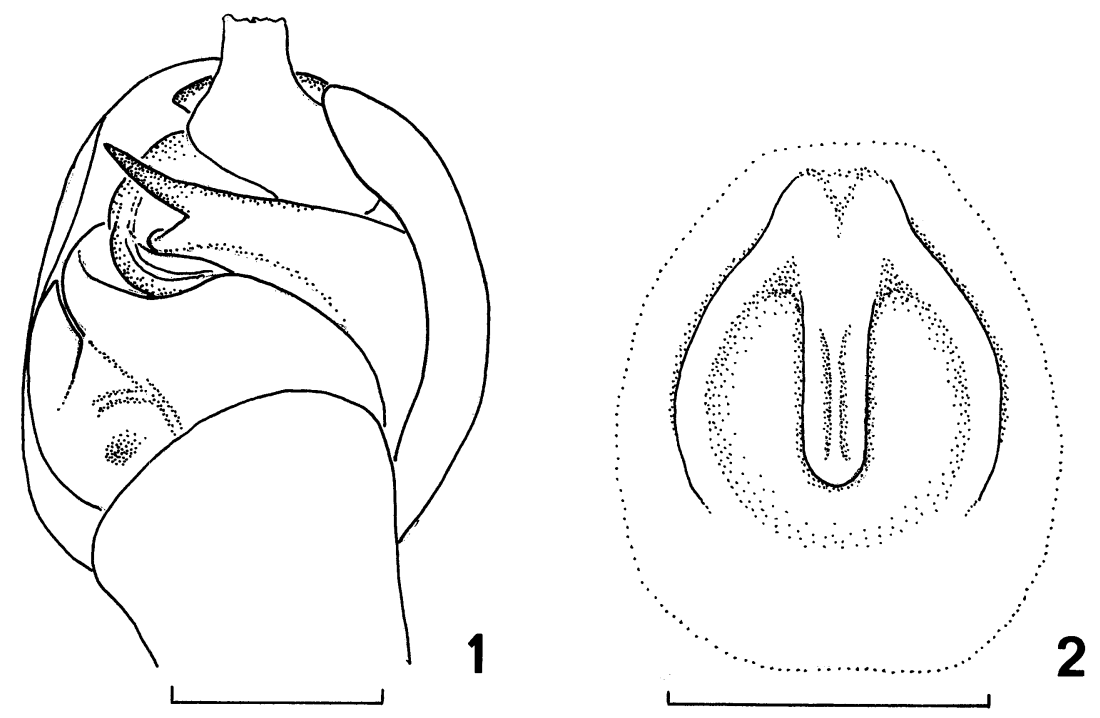

Figs. 1-2. Argyrodes fissifrons O. Pickard-Cambridge, 1869. — 1, Male left palp, ventral view (syntype, BM7861-2); 2, epigynum (syntype, BM7861-2). (Scales: 0.25 $\mathrm{mm}$. 


\section{Argyrodes fissifrons O. Pickard-Cambridge, 1869}

(Figs. 1-2)

Argyrodes fissifrons O. P.-Cambridge, 1869, p. 380, figs. 31-38 (syntypes from Ceylon, preserved in the Natural History Museum, London, examined); Chrysanthus, 1963 , p. 737 , figs. $55-58$.

Argyrodes menlunensis Zhu et Song, 1991, p.139 (female holotype from Menglun, Yunnan, China, not examined); Zhu, 1998, p.220, fig. 144. SYN. NOV.

Specimens examined. Type series. Syntypes: 1 우 $1 \sigma^{7}$, Ceylon (=Sri Lanka) (BM 7861-2).

Other specimens examined. $1 \sigma^{\curlyvee}$, Ceylon (=Sri Lanka) (BM 15.3.5.2.37.38). 1 우 1 Ђ7, Wamena, Irian Jaya, Indonesia, 31-VII-3-VIII-1982, A. Tanikawa leg. 2 우 1 ㄲ, Jayapura, Irian Jaya, Indonesia, 4-5-VIII-1982, A. Tanikawa leg.

Argyrodes kumadai sp. nov.

(Figs. 3-8)

Argyrodes fissifrons: Bösenberg \& Strand, 1906, p.130, figs.48, 235, 236, 240; Shinkai \& Takano, 1984, p.52; Yaginuma, 1986, p.51, figs. 28-2; Chikuni, 1989, p.34, fig. 23; Zhu \& Song, 1991, p.134, fig.5; Zhu, 1998, p.206, fig.134. [Nec Argyrodes fissifrons O. Pickard-Cambridge, 1869.]

Specimens examined. Type series. Holotype: 우, Cape Hedo-misaki, Kunigamison, Okinawajima Island, Okinawa Prefectureecture, Japan, 18-VII-1987, A. Shinkai leg. (NSMT-Ar 4181).

Paratypes: 1 우, Kotokuji, Akiruno-shi, Tokyo, 16-X-1983, K. Kumada leg. (NSMT-Ar 4182). $1 \sigma^{7}$, Tateyama-shi, Chiba Prefecture., 30-VII-1977, S. Matsumoto leg. (NSMT-Ar 4183). 1 우, Tsukui Shiroyama, Tsukui-cho, Kanagawa Prefecture., 17- VII-1983, A. Tanikawa leg. (NSMT-Ar 4184). $1 \sigma^{7}$, Noba-cho, Yokohama-shi, Kanagawa Prefecture., 19-VII-1980, T. Ueno leg. (NSMT-Ar 4185). 1 व , Ichiyama, Tagata-gun, Shizuoka Prefecture. 31-VII-1982, K. Kumada leg. (NSMT-Ar 4186). 1 우, 20-VIII-1980 (NSMT-Ar 4187), 1 우, 11-VIII-1981 (NSMT-Ar 4188), Kokubucho, Suzuka-shi, Mie Prefecture. A. Uyemura leg. $1 \sigma^{\nearrow}$, Nan-gusuku, Nago-shi, Okinawajima Island, Okinawa Prefecture., 18-VII-1987, A. Shinkai leg. (NSMT-Ar 4189). 1 $\sigma^{7}$, same data as for the holotype (NSMT-Ar 4190). 1 우, 17-VIII-1985 (NSMT-Ar 4191), 1 ठ , 24-VIII-1987 (NSMT-Ar 4192), Tsukigahama, Iriomotejima Island, Okinawa Prefecture, A. Tanikawa leg.

Other specimens examined: JAPAN. 67 우 29 o from Tokyo, Chiba, Kanagawa, Shizuoka, Gifu, Mie, Wakayama, Okayama, Oita, Miyazaki, Kagoshima, and Okinawa Prefectures. TAIWAN. 3 ㅇ 3 万ु, Nanshanhsi, 28-XII-1994, T. Kimura leg.

Description (based on the female holotype and one of the male paratypes; variations among type series are given in the parentheses). Measurement (in $\mathrm{mm}$ ). Total length 우 10.32 (4.32-10.80), o 6.72 (3.44-7.44); carapace length 우 3.04 (1.76-2.64), 아 2.56 (1.60- 2.80); width 우 1.84 (1.12-1.60), 이 1.52 (1.04-1.60); abdomen length 우 7.44 (2.64- 7.52), o7 4.32 (1.68-4.64), width 우 2.88 (1.28-3.84), 가 1.52 (0.80-1.76); height 우 5.04 (1.52-5.20), ه $2.40(0.88-2.40)$. Length of legs of the female holotype and one of the male paratypes from Okinawa Prefecture (NSMT-Ar 4181, 4189; Tarsus + Metatarsus + Patella and Tibia + Femur $=$ Total $):$ ㅇ I, $3.20+8.08+8.16+8.32=27.76$; II, $2.40+$ 

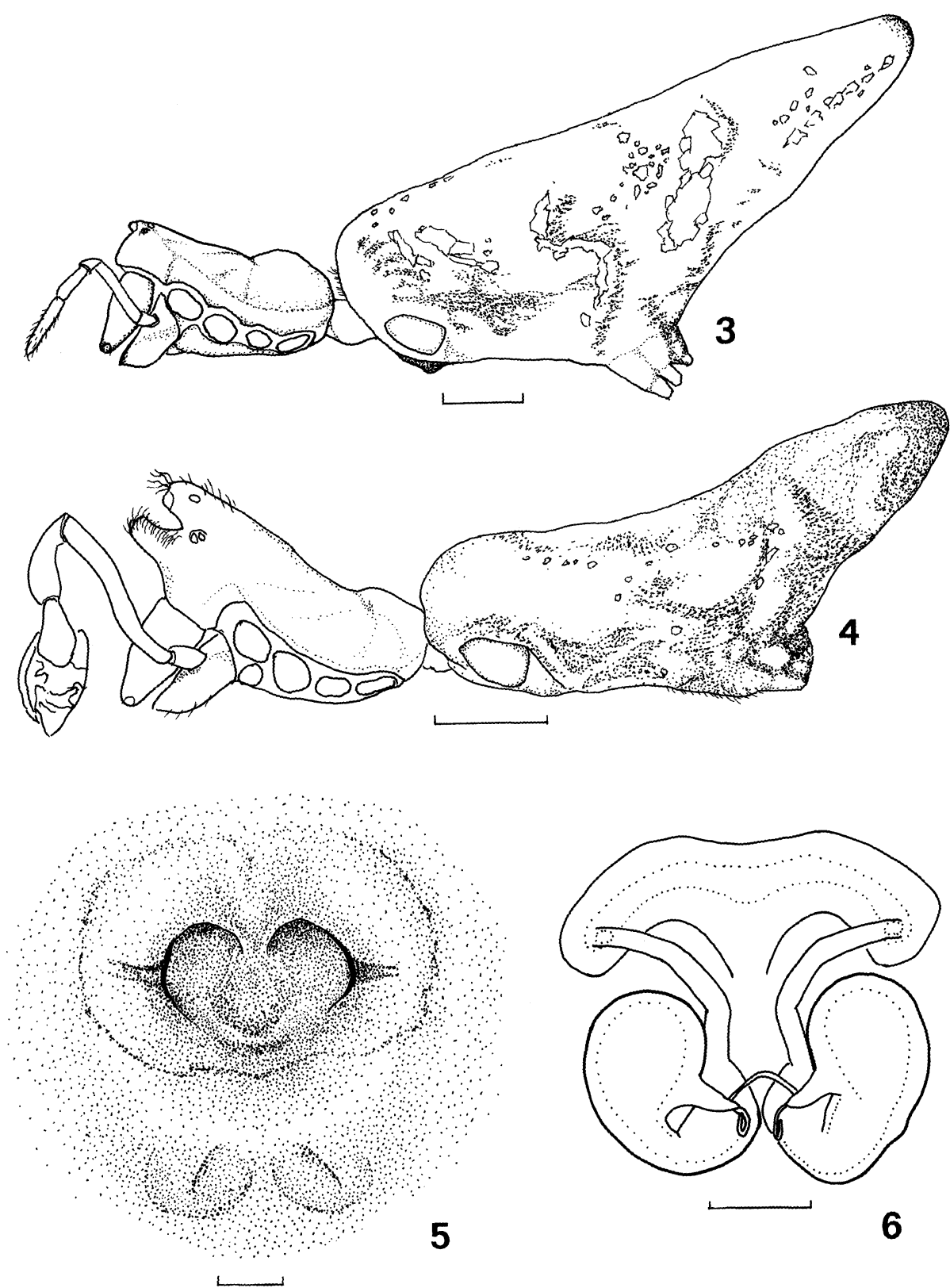

Figs. 3-6. Argyrodes kumadai sp. nov. - 3, female, lateral view, legs omitted (holotype, NSMT-Ar 4181); 4, male, lateral view, legs omitted (paratype, NSMTAr 4189); 5, epigynum (holotype, NSMT-Ar 4181); 6, female genitalia (holotype, NSMT-Ar 4181). (Scales: 3-4, $1 \mathrm{~mm} ; 5-6,0.1 \mathrm{~mm}$.) 

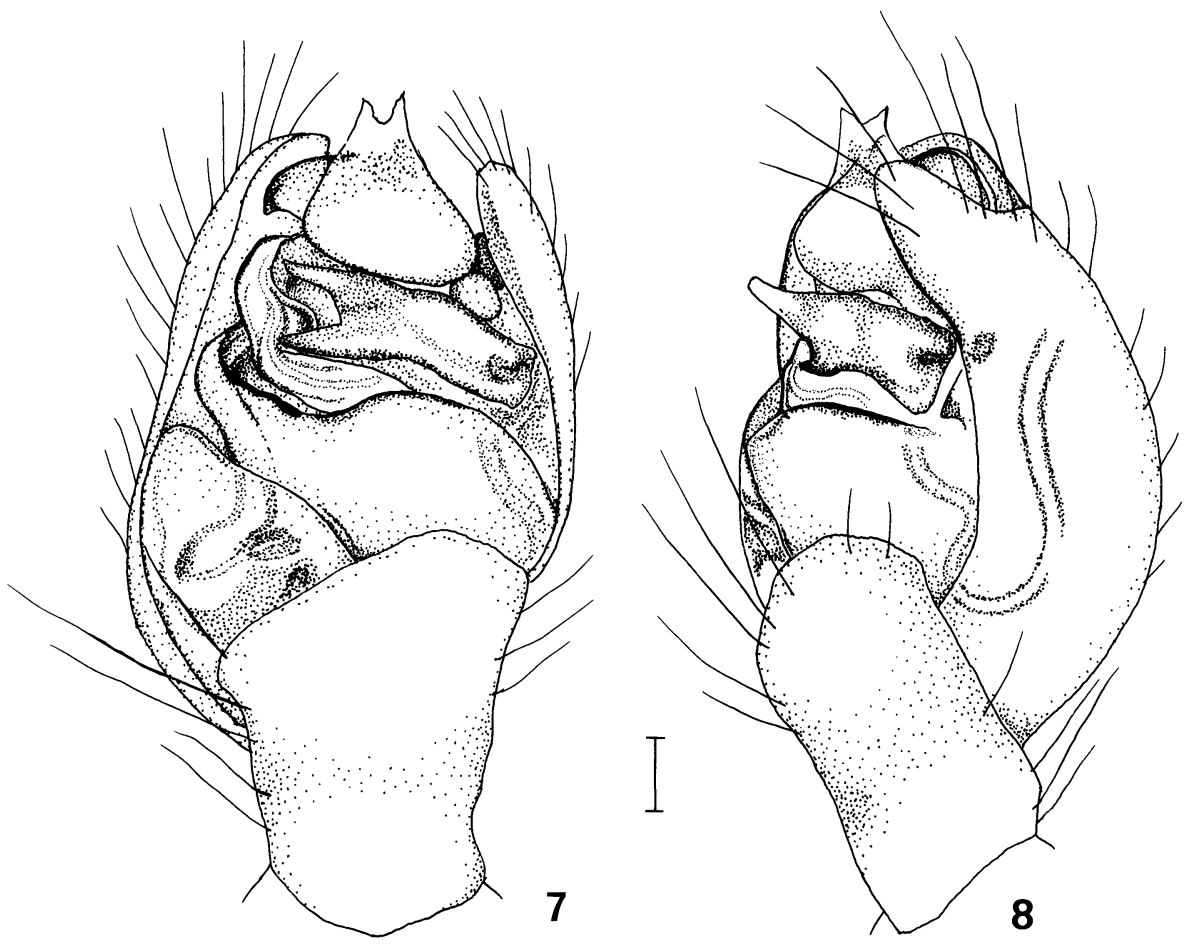

Fig. 7-8. Argyrodes kumadai sp. nov. 7, Male left palp, ventral view (paratype, NSMT-Ar 4189); 8, same, lateral view (paratype, NSMT-Ar 4189)

$4.88+5.04+5.60=17.92 ;$ III, $1.52+2.64+2.56+3.36=10.08 ;$ IV, $2.48+5.20+5.36+$ $6.40=19.44$. व I I, $2.64+6.00+6.56+6.16=21.36 ;$ II, $2.08+3.84+4.08+4.00=14.00 ;$ III, $1.28+2.00+2.00+2.48=7.76 ; \mathrm{IV}, 2.00+3.52+3.92+4.32=13.76$

Female and male: Carapace length/width 우 1.65 (1.57-1.69), 아 1.68 (1.54-1.83). Male palp as shown in Figs. 7-8. Abdomen elongated triangle in lateral view (Figs. $3-4)$, length/width 우 2.58 (1.82-2.58), 유 2.84 (2.10-2.84), height/length 우 0.68 (0.57$0.73)$, o $0.56(0.52-0.65)$. Female genitalia as shown in Figs. 5-6.

Coloration and markings in alcohol. Female and male: Carapace dark brown. Legs light brown with dark brown annulation. Abdomen brown with black markings and silver markings.

Range. Japan (except northern part), Taiwan, China.

Remarks. This species closely resembles Argyrodes fissifrons. Males of these two species can not be separated even by the palpal structure (Figs. 1,7) as well as general appearance. These species can be distinguished by the feature of the female genital organ (Figs. 2, 5).

Etymology. Named after Mr. Ken-ichi Kumada, Mie. 


\section{摘 要}

チリイソウロウグモは Bösenberg \& Strand (1906) によって Argyrodes fissifrons O. Pickard-Cambridge, 1880 と同定され，日本から記録された。しかし，基準標本との比較 の結果，この同定は誤りであることが判明した。また，その他の既記載のイソウロウグ モ類のいずれにも同定することができなかったので, Argyrodes kumadai sp. nov.の学 名のもとに新種として記載した。和名については従来通りチリイソウロウグモを使用し たい.さらに，中国から記載された Argyrodes menlunensis Zhu et Song, 1991 は，原記 載における外雌器の図から判断して $A$. fissifrons の新参シノニムとした.

\section{References}

Bonnet, P., 1955. Bibliographia Araneorum, 2(1), pp. 1-918. Toulouse.

Bösenberg, W., \& E. Strand, 1906. Japanische Spinnen. Abh. senckenb. naturf. Ges., 30: 93-422, pls. 3-16.

Brignoli, P. M., 1983. A Catalogue of the Araneae Described between 1940 and 1981. $755 \mathrm{pp}$. Manchester University Press, Manchester and New York.

Chikuni, Y., 1989. Pictorial Encyclopedia of Spiders in Japan. 308 pp. Kaisei-sha, Tokyo. (In Japanese.)

Chrysanthus, F., 1963. Spiders from South New Guinea. V. Nova Guinea, Zool., (24): 727-750.

Chrysanthus, F., 1975. Further notes on the spiders of New Guinea II (Araneae, Tetragnathidae, Theridiidae). Zool. Verh., (140): 3-50.

Pickard-Cambridge, O., 1869. Part I of catalogue of a collection of Ceylon Araneidea lately received from Mr. J. Nietner, with description of new species and characters of a new genus. J. Linn. Soc. London, 10: 373-397.

Platnick, N. I., 1989. Advances in Spider Taxonomy, 1981-1987. 673 pp. Manchester University Press, Manchester \& New York.

Platnick, N. I., 1993. Advances in Spider Taxonomy, 1988-1991. 846 pp. New York Entomological Society \& The American Museum of Natural History, New York.

Platnick, N. I., 1997. Advances in Spider Taxonomy, 1992-1995. 976 pp. New York Entomological Society \& The American Museum of Natural History, New York.

Shinkai, E., \& S. Takano, 1984. A Field Guide to the Spider of Japan. 206 pp. Tokai Univ. Press, Tokyo. (In Japanese.)

Yaginuma, T., 1986. Spiders of Japan in Color, (n. ed.). 305 pp., 64 pls. Hoikusha, Osaka. (In Japanese.)

Zhu, M. S., 1998. Fauna Sinica. Arachnida, Araneae, Theridiidae. 436 p. Science Press, Beijing.

Zhu, M.-S. \& D.-X. Song, 1991. Notes on the genus Argyrodes from China (Araneae: Theridiidae). J. Hebei educ. Coll., Nat. Sci. Ed., 1991(4): 130-146. 